BHI-0984

Rev. 0

\title{
105-N Basin Sediment Disposition Phase-Two Sampling and Analysis Plan
}

Author

R. C. Smith

Date Published

March 1997

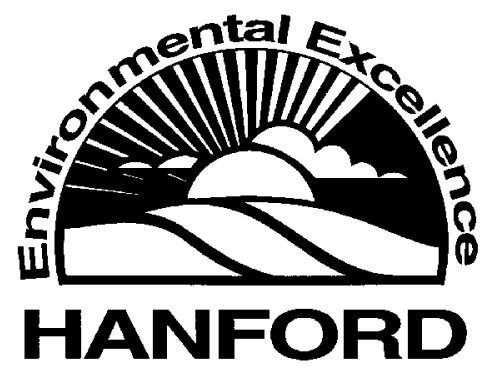

Prepared for the U.S. Department of Energy

Office of Environmental Restoration

Bechtel Hanford, Inc.

Richland, Washington 
TRADEMARK DISCLAIMER

Reference herein to any specific commercial product, process, or service by trade name, trademark, manufacturer, or otherwise, does not necessarily constitute or imply its endorsement, recommendation, or favoring by the United States Govemment or any agency thereof or its contractors or subcontractors.

This report has been reproduced from the best available copy. Available in paper copy and microfiche.

Available to the U.S. Department of Energy

and its contractors from

Office of Scientific and Technical Information

P.O. Box 62

Oak Ridge, TN 37831

(615) $576-8401$

Available to the public from the U.S. Department of Commerce

National Technical Information Service

5285 Port Royal Road

Springfield, VA 22161

(703) $487-4650$

Printed in the United States of America

DISCLM-5.CHP (8-91) 
BHI-00984

Rev. 0

\section{CONTENTS}

1.0 INTRODUCTION $\ldots \ldots \ldots \ldots \ldots \ldots \ldots \ldots \ldots \ldots \ldots \ldots \ldots \ldots \ldots$

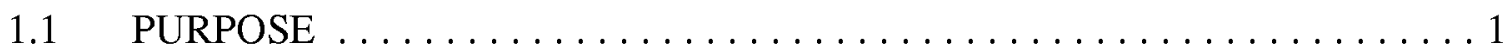

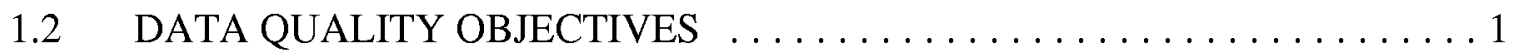

1.3 SAMPLING AND ANALYSIS OBJECTIVES $\ldots \ldots \ldots \ldots \ldots \ldots \ldots \ldots$

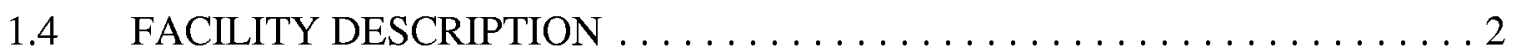

1.5 PROCESS KNOWLEDGE $\ldots \ldots \ldots \ldots \ldots \ldots \ldots \ldots \ldots \ldots \ldots \ldots \ldots$

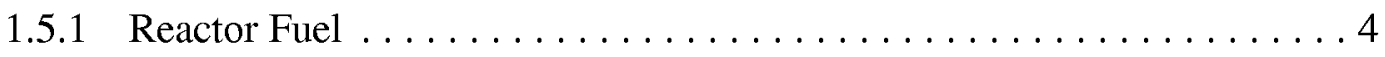

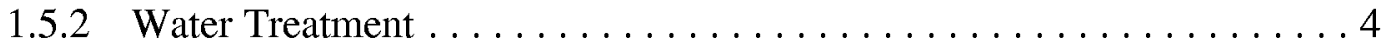

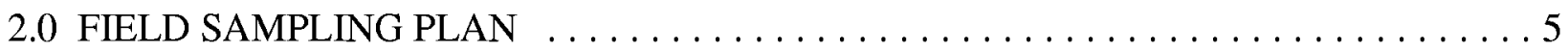

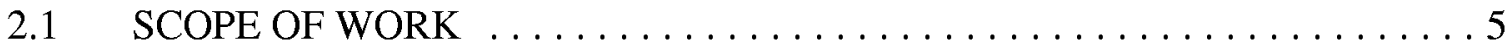

2.2 SAMPLE COLLECTION AND SAMPLING LOCATION $\ldots \ldots \ldots \ldots \ldots$

2.3 FIELD DOCUMENTATION OF SAMPLING $\ldots \ldots \ldots \ldots \ldots \ldots \ldots \ldots$

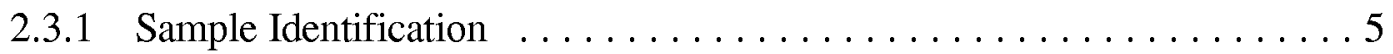

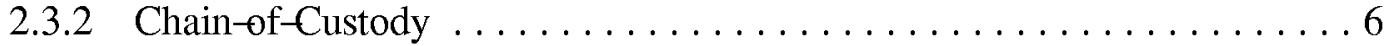

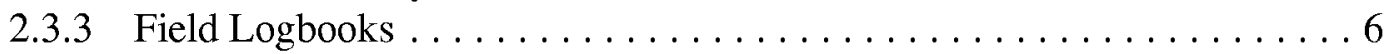

2.4 DECONTAMINATION OF SAMPLING EQUIPMENT $\ldots \ldots \ldots \ldots \ldots \ldots$

2.5 SAMPLE PACKAGING AND SHIPMENT $\ldots \ldots \ldots \ldots \ldots \ldots \ldots \ldots \ldots$

2.6 MANAGEMENT OF INVESTIGATION DERIVED WASTE $\ldots \ldots \ldots \ldots .7$

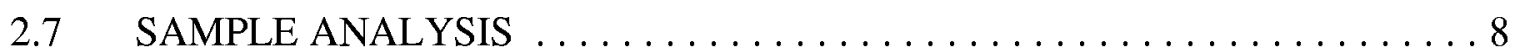

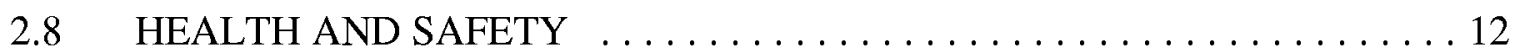

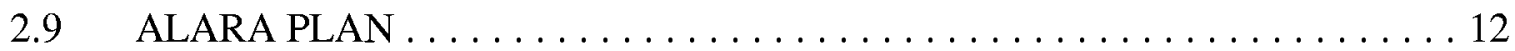

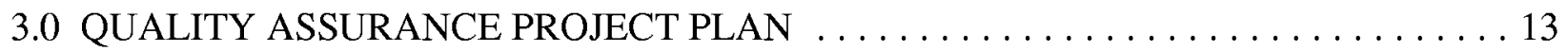

3.1 PROJECT ORGANIZATION AND RESPONSIBILITY $\ldots \ldots \ldots \ldots \ldots \ldots$

3.1 .1 Technical Lead Responsibility . . . . . . . . . . . . . . . . . . . 13

3.1 .2 Support Responsibilities . . . . . . . . . . . . . . . 13

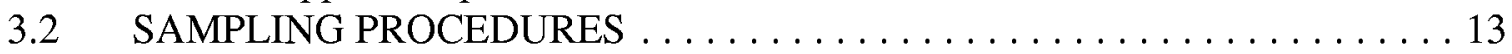

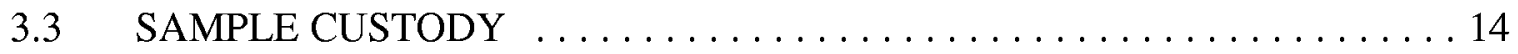

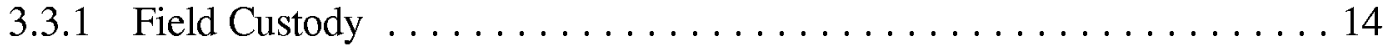

3.3.2 Laboratory Custody Procedure . . . . . . . . . . . . . . . . 14

3.3.3 Final Evidence Custody Procedure . . . . . . . . . . . . . 14

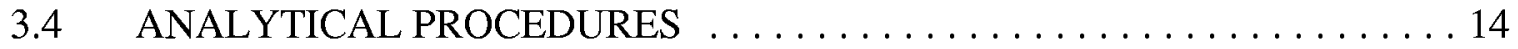

3.5 OBJECTIVES FOR ANALYTICAL MEASUREMENTS $\ldots \ldots \ldots \ldots \ldots \ldots 14$

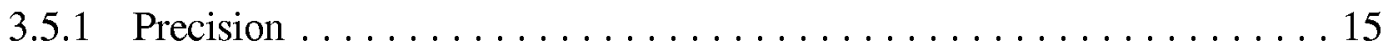

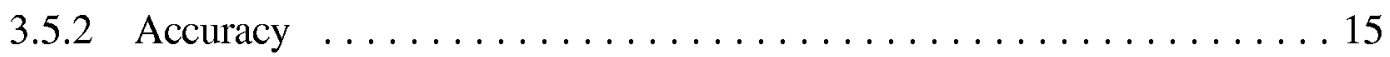

3.5 .3 Representativeness ............................. 15

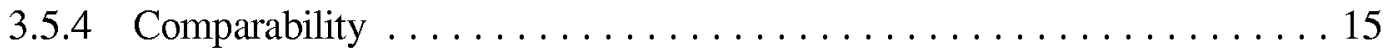

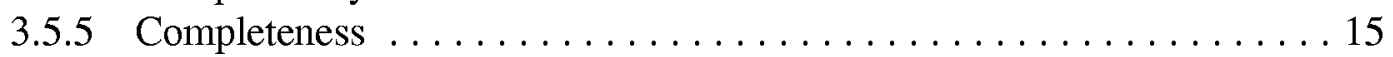

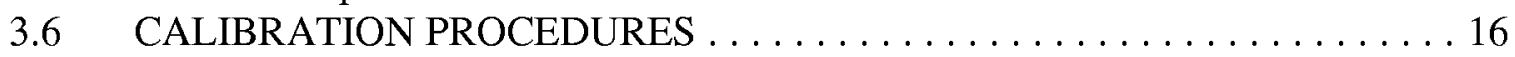


3.7 INTERNAL QUALITY CONTROL $\ldots \ldots \ldots \ldots \ldots \ldots \ldots \ldots \ldots \ldots \ldots \ldots \ldots$

3.7.1 Field Quality Control Requirements $\ldots \ldots \ldots \ldots \ldots \ldots \ldots \ldots$

3.7.2 Analytical Laboratory Quality Control Requirements . . . . . . . . . . 16

3.8 DATA REPORTING AND MANAGEMENT $\ldots \ldots \ldots \ldots \ldots \ldots \ldots \ldots$

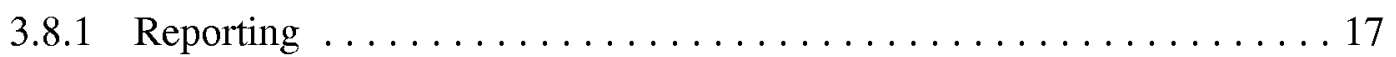

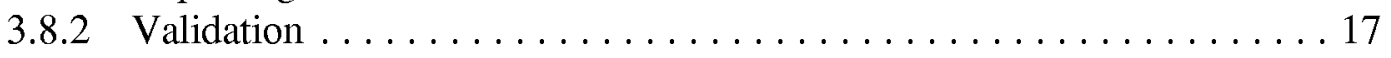

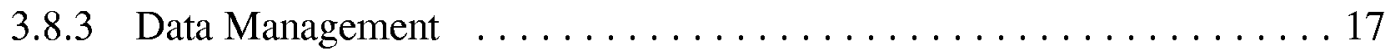

3.9 PERFORMANCE AND SYSTEMS AUDITS $\ldots \ldots \ldots \ldots \ldots \ldots \ldots \ldots$

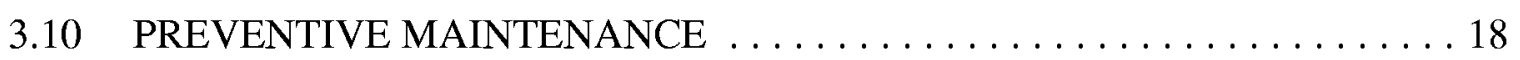

3.11 DATA ASSESSMENT PROCEDURES $\ldots \ldots \ldots \ldots \ldots \ldots \ldots \ldots \ldots \ldots$

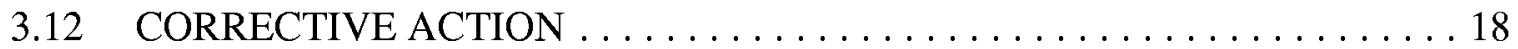

3.13 QUALITY ASSURANCE REPORTS $\ldots \ldots \ldots \ldots \ldots \ldots \ldots \ldots \ldots$

4.0 REFERENCES ....................................... 19

\section{FIGURE}

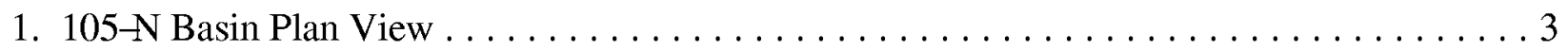

\section{TABLE}

1. Required Analytical Parameters, Analytical Methods, and Target Practical Quantitation Limits for the 105-N Basin (North Cask Pit) Sediment Sample(s) ................ 9 
BHI-00984

Rev. 0

\subsection{INTRODUCTION}

The sampling and analysis plan (SAP) for Phase 2 of the $105-\mathrm{N}$ Basin sediment disposition task defines the sampling and analytical activities that will be performed to support characterization of the sediment and selection of an appropriate sediment disposal option. A separate SAP (BHI 1997) defines the sampling and analytical activities that will be performed for the engineering assessment phase (Phase 1) of the $105-\mathrm{N}$ sediment disposition task. The Phase-2 SAP is presented in the introduction (Section 1.0), in the field sampling plan (FSP) (Section 2.0), and in the quality assurance project plan (QAPjP) (Section 3.0). The FSP defines the sampling and analytical methodologies to be performed. The QAPjP provides information on the quality assurance/quality control (QA/QC) parameters related to the sampling and analytical methodologies.

\subsection{PURPOSE}

This SAP defines the strategy and the methods that will be used to sample and analyze the sediment in the $105-\mathrm{N}$ Basin North Cask Pit after transferring all of the 105- $\mathrm{N}$ Basin floor sediment to the pit. The resulting data will be used to characterize the sediment from the basin. Characterization results will be compared to waste acceptance criteria to support final disposition of the sediment.

\subsection{DATA QUALITY OBJECTIVES}

The objectives and goals for this project were defined in a U.S. Department of Energy, Richland Operations Office (DOE-RL) data quality objectives (DQO) process workshop. The DQO was conducted following the U.S. Environmental Protection Agency's (EPA) Guidance for the Data Quality Objectives Process (EPA 1994). The DQO participants included the DOE-RL 100-N Area Project Manager, the Washington State Department of Ecology (Ecology) 100-N Area Project Manager, an Environmental Restoration Contractor (ERC) DQO facilitator, and ERC $100-\mathrm{N}$ Area project and functional personnel. The team utilized the ERC's DQO process to accomplish the following objectives:

C Identify and resolve key project issues related to the purpose of the project

C Determine parameters of interest

C Determine analytical methods, data quality needs, and data use

C Design the sample collection strategy (location and frequency)

C Define the uncertainties associated with the project.

The results of the DQO are reported in the Bechtel Hanford, Inc. (BHI) report, Data Quality Objectives Summary Report for the 105 N Basin Sediment Disposition (BHI 1996a). This SAP represents a resource-effective sampling and analytical effort that was mutually agreed upon by 
BHI-00984

Rev. 0

the DOE-RL, Ecology, and the ERC project team. This SAP satisfies the DQO requirements for sampling and analyzing the sediment in the $105-\mathrm{N}$ Basin to support characterization.

\subsection{SAMPLING AND ANALYSIS OBJECTIVES}

The primary objective of the sampling and analysis activities is to provide radiological, chemical, and physical properties data to characterize the sediment in the 105-N Basin to support final disposition of the sediment. Specific goals to achieve this objective include the following tasks:

C Obtain one representative sample of the sediment from the North Cask Pit. The sample will be prepared and analyzed by the Project Hanford Management Contractor's (PHMC) $222-S$ Analytical Laboratory $(222-S)$.

C Determine radiological, chemical, and physical properties of the sediment necessary for characterization. Results will be compared to various waste acceptance criteria to determine what disposition alternatives are available.

C If necessary, perform additional analysis to support disposal at Tank Waste Remediation System.

\subsection{FACILITY DESCRIPTION}

The purpose of the $105-\mathrm{N}$ Basin was to receive, segregate, and store spent fuel during $\mathrm{N}$ Reactor operation. The basin provided cooling for the spent fuel and a secure place to allow short-lived isotopes to decay. The water in the basin provided workers with shielding from the nuclear radiation that resulted from the isotope decay while the workers sorted and handled the fuel elements underwater.

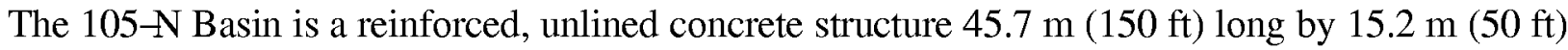

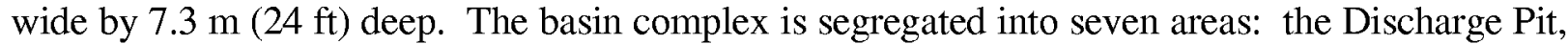
the Segregation Pit, the Exam Pit, the North Basin, the South Basin, the North Cask Pit, and the South Cask Pit (Figure 1). These areas share a common pool of water [totaling approximately 3.8 million liters ( 1 million gallons)]. A sediment layer distributed across the bottom of the $105-\mathrm{N}$ Basin is a nonhomogeneous mixture of particulate materials possibly containing fuel element corrosion products; environmental materials (e.g., sand and insects); rack, canister, and equipment corrosion products; sloughed-off concrete material; paint flakes from racks; and fission products. 


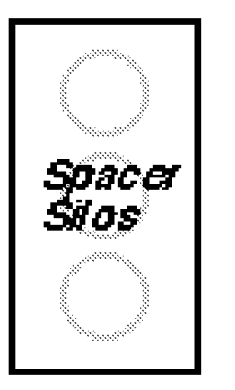

\section{N Basin Plan View}

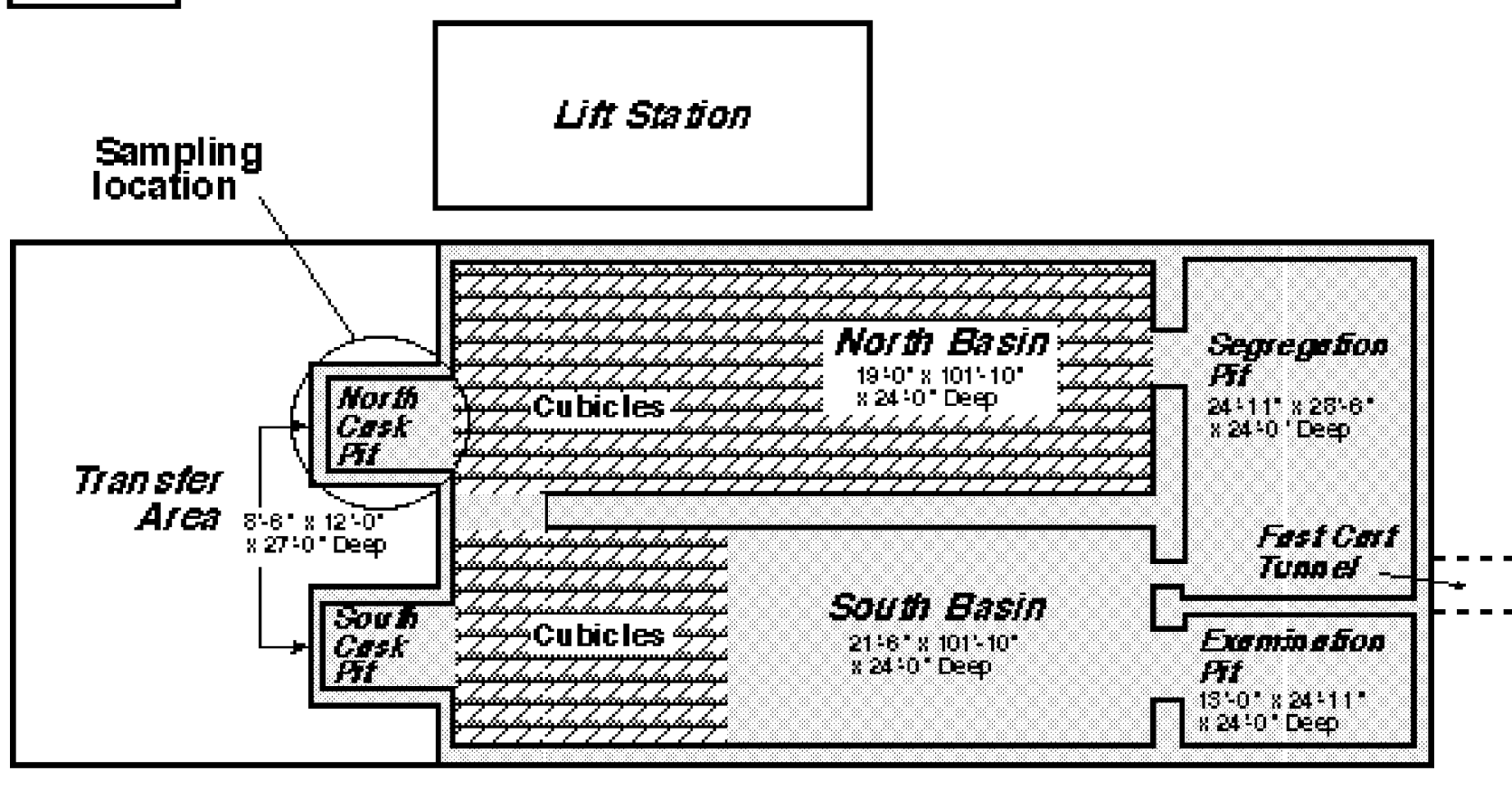

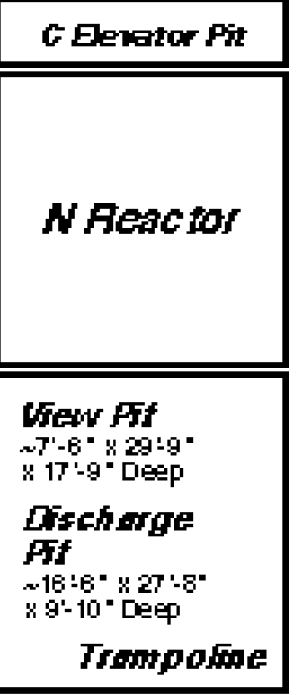


BHI-00984

Rev. 0

\subsection{PROCESS KNOWLEDGE}

\subsubsection{Reactor Fuel}

The N Reactor's fuel is metallic uranium (uranium-238 slightly enriched with uranium-235) clad in a zirconium alloy. The process tube is a concentric tube-within-a-tube design. Outer fuel elements are approximately $5 \mathrm{~cm}$ (2 in.) in diameter and $43 \mathrm{~cm}$ (17 in.) to $66 \mathrm{~cm}$ (26 in.) in length. Inner elements are the same length as the outer element, and they are approximately $2.54 \mathrm{~cm}$ (1 in.) in diameter with a small center hole for coolant circulation. Standoffs were used between the inner and outer elements and between the outer element and the process tube to maintain annular coolant flow. Carbon-steel cylindrical perforated spacers, 43 to $55.8 \mathrm{~cm}$ (17 to 22 in.) in length, were located before and after the fuel to place it within the process tube for flux shaping.

Fuel was supplied in either $0.95 \%$ or $1.25 \%$ uranium -235 enrichments. Depending on defense production requirements, operating cycles ranged from 30 to 90 or more days. Refueling outages replaced about one-third of the core inventory (approximately 6,000 fuel assemblies). Operating personnel have observed that approximately $1 \%$ of the fuel was damaged during discharge, most commonly through contact with the top edge of the transport carts. Fuel damage consisted of cladding cracks, end-fitting failures, and full breaks. Although operating personnel retrieved and packaged $99+\%$ of the discharged fuel, direct fuel contact with the $105-\mathrm{N}$ Basin water and corrosion of broken fuel provided a source of fissile material to basin sediment.

\subsubsection{Water Treatment}

There have been three distinct phases of water treatment throughout the history of $\mathrm{N}$ Reactor. The first phase of water treatment was from 1964 to 1984. During this period, potable water (treated Columbia River water) was used as the source for a feed-and-bleed makeup system. There was some water circulation driven by thermal currents that resulted from stored fuel in the cubicles, up to the weirs, and then to the lift station. Overflow weirs were used to remove the "scum layer" from the water surface.

During the period 1984 through 1989, the 107-N Recirculation Cooling Building provided direct circulation, filtration, ion exchange, and cooling for $105-\mathrm{N}$ Basin water. Makeup to the $105-\mathrm{N}$ Basin was still provided by potable water. When the $107-\mathrm{N}$ Building was shut down in 1989 , $\mathrm{N}$ Basin water treatment ceased except for the addition of water to replace that lost through evaporation.

In 1995, water filtration was initiated through the use of back-flushable and disposable filters with a pore size of 5 microns. During 1996, sodium hypochlorite and hydrogen peroxide were periodically added to the basin water to control algae, and sulphuric acid was added to adjust the $\mathrm{pH}$. 
BHI-00984

Rev. 0

\subsection{FIELD SAMPLING PLAN}

The FSP outlines the strategy and procedures to be used for sediment collection and sample analysis to provide information to support characterization. The selection of analytical parameters, laboratory arrangements, sample locations and frequencies, sampling equipment selection, and QC measures are based on the DQOs (BHI 1996a) and the sampling objectives described in Section 1.0 of this SAP. Samples will be analyzed for radiological, chemical, and physical parameters.

\section{$2.1 \quad$ SCOPE OF WORK}

The scope of the FSP is limited to one sediment sample (composited from 3 sediment samples) that comprises the characterization phase (Phase 2) of the $105-\mathrm{N}$ Basin sediment disposition project. The sample(s) will be analyzed at the PHMC's 222-S Analytical Laboratory. Details of planned sampling and analytical activities are discussed in the following subsections.

\subsection{SAMPLE COLLECTION AND SAMPLING LOCATION}

General procedures for sample collection are described in BHI-EE-01, Environmental Investigation Procedures (EIP). North Cask Pit sediment samples will be collected using an underwater sludge-sample collection tool (FS-UWSS -1 ). A detailed description of the sampling tool and the procedure for its operation will be attached to the sampling activity work control package.

After all sediment has been moved to the North Cask Pit and homogenized, three samples will be collected from the North Cask Pit. These three samples will be composited, and up to 4 liters (1.06 gallons) of composited sample will be collected in a plastic carboy or multiple 1-iter containers. To meet analytical needs, approximately $500 \mathrm{~mL}$ (15 ounces) of settled solid (i.e., sediment) are required. Sample personnel will use field judgement to determine if a sample meets the analytical volume requirement and should be sent to the laboratory.

\subsection{FIELD DOCUMENTATION OF SAMPLING}

This section describes the procedures to be followed for sample identification, chain-of-custody, and field logbook documentation.

\subsubsection{Sample Identification}

The ERC's Sample Data Tracking database will be used to track the composited sample and the analytical data. Prior to initiating field sampling activities, Hanford Environmental Information System (HEIS) sample numbers for this project will be issued to the sampling organization in 
BHI-00984

Rev. 0

accordance with BHI-EE-01, EIP 2.0, "Sample Event Coordination." The sample will be identified and labeled with a unique HEIS sample number. The sample location and corresponding HEIS number will be documented in the field sampling logbook. Each sample container will be labeled with the following information using a waterproof marker on a firmly affixed, water-resistant label: HEIS number, sample collection date/time, name/initials of sampler, analyses required, and preservation method, if applicable.

\subsubsection{Chain-of-Custody}

The composited sample will be controlled from the point of origin to the analytical laboratory in accordance with BHI-EE-01, EIP 3.0, "Chain of Custody." A chain-of-eustody record will be initiated in the field at the time of sampling and will accompany each sample set to the laboratory. Chain-of-eustody procedures will be followed throughout the sample collection and transfer to the laboratory to ensure that the integrity of the sample is maintained. A custody seal (i.e., evidence tape) will be affixed to the lid of each sample jar. The custody seal will be initialed and dated by the sampler at the time the sample container is sealed. If the dose rate is too high, the custody seal will be applied to the outer shipping container.

\subsubsection{Field Logbooks}

All information pertinent to field sampling, including sample location and HEIS number, will be recorded in bound logbooks in accordance with BHI-EE-01, EIP 1.5, "Field Logbooks." The sampling team will be responsible for recording all relevant sampling information including, but not limited to, the information listed in Appendix A of EIP 1.5. Entries made in the logbook will be dated and signed by the individual making the entry.

\subsection{DECONTAMINATION OF SAMPLING EQUIPMENT}

The sediment sample collection tool will be field cleaned with non-phosphate soap and water and then rinsed with deionized water before the first use of the tool. An equipment blank will then be collected as described in subsection 3.7.1.1 of this SAP. If possible, the portion of the sample tool that collects the sample will be replaced with spare parts, as available, to minimize sample cross-eontamination. All equipment will be handled in a manner that will minimize crosscontamination between sample locations.

After sample collection, equipment will be field cleaned to the extent practical by rinsing and wiping. The equipment will be surveyed to be free of radiological contamination or it will be wrapped in plastic and controlled in accordance to radiological control requirements. Any components of the sediment sample tool that come into direct contact with the sample should be as free of radiological contamination as possible to minimize cross-contamination at the next sample location. 
BHI-00984

Rev. 0

\subsection{SAMPLE PACKAGING AND SHIPMENT}

Sample packaging and shipping will be performed in compliance with BHI-EE-01, EIP 3.1, "Sample Packaging and Shipping." The sediment sample will be collected in accordance with container sizes and types specified in the Sample Authorization Form/Field Sample Requirements (SAF/FSR) form prepared by ERC's Sample and Data Management (SDM) organization. All samples will be shipped to the $222-S$ Analytical Laboratory in accordance with U.S. Department of Transportation (DOT) requirements found in 49 CFR 171-173. The outside of each sample bottle will be surveyed by the radiological control technician (RCT) to be free of smearable surface contamination in accordance with BHI-SH-04, Radiological Control Work Instructions. In addition, the RCT will measure the radiological activity on the outside of each sample container (through the container) and will mark the container with the highest contact radiological reading in either disintegrations per minute or mrem/hr, as applicable. Each sample container will be labeled with the word "Radioactive" in accordance with DOT requirements. Samples will be stored in a radioactive materials management area at $100-\mathrm{N}$ until packaging and shipment arrangements are finalized for each sample shipment.

Evaluation of historical data, in combination with dose rate estimate sample collection activities, indicates that samples will be shipped as DOT 7A Type A radioactive material shipments. Onsite sample shipments will follow DOT, or equivalent safety requirements.

Sample shipment arrangements to $222-S$ will be made for each shipment based upon the radiological activity and dose rate for each sample set. Samples will be shipped in one of the following packages:

C DOT 7A Type A shipping cooler provided by the ERC Field Sampling organization. This packaging holds up to twelve 1 -iter containers and is accepted for shipments of up to Type A radioactive materials with dose rates up to $1,000 \mathrm{mR} / \mathrm{hr}$. If the outside of the package exceeds $200 \mathrm{mR} / \mathrm{hr}$, then the shipment will be marked as "exclusive use," as specified in 49 CFR 173.

C $222-S$ Laboratory Hedgehog Sample Shipping packaging. This packaging will be provided by the $222-S$ Laboratory and can hold a 1 titer sample jar or smaller.

C PAS -1 Cask for samples whose dose rate exceeds DOT 7A packaging requirements or other ALARA criteria.

Any sample shipments that require DOT placarding (i.e., radioactive yellow III label) will be transported by BHI Field Support qualified drivers.

\subsection{MANAGEMENT OF INVESTIGATION DERIVED WASTE}

All investigation derived waste generated during field sampling will be handled in accordance with BHI waste management requirements specified in BHI-EE-02, Environmental Requirements 
BHI-00984

Rev. 0

and in accordance with the Engineering Evaluation/Cost Analysis for 100-N Area Waste (BHI 1996b). Prior to undertaking activities associated with this SAP, a waste management plan will be developed detailing specific methods for handling and disposition of associated sampling wastes. Efforts will be made to minimize not only the volume of sediment and water wastes derived from sampling and decontamination procedures, but the volume of personal protective equipment waste as well. Field screening and waste management procedures will be used to assist in segregation of radiological waste from clean waste. Sampling equipment that cannot be successfully decontaminated and cannot be used further will be managed as waste. Unused sample material that is no longer needed, as directed by the 105- $\mathrm{N}$ Basin Project Task Lead, will be returned to the 105- $\mathrm{N}$ Basin Project for disposal to the associated waste accumulation area where it was collected, or arrangements made for disposal by the laboratory.

\subsection{SAMPLE ANALYSIS}

Sample analysis methods, preservation, hold times, and volume requirements will be identified through the process defined by BHI-EE-01, EIP 2.0, "Sample Event Coordination," and documented on the SAF/FSR form.

Analyses will be performed by the PHMC's 222-S Analytical Laboratory. Detailed instructions for the laboratory on receiving, handling, processing, and analyzing the sample are provided in an analytical instructions (AI) document from the ERC-SDM. Table 1 summarizes required analytical parameters, analytical methods, and target practical quantitation limits.

The sediment sample will be transferred to the analytical laboratory as one unit or possibly in multiple containers to reduce radiological dose. Approximately $500 \mathrm{ml}$ (15 ounces) of settled solids will be required to perform the analyses. If a sediment sample is collected in multiple containers, then the laboratory must homogenize and recombine multiple sample containers prior to initiating any analysis. If a sediment sample includes sediment collected on a filter media in addition to containerized sediment, the lab will add this material to the solids of the other containerized sediment associated with that particular sample.

Some of the sediment physical properties, such as viscosity and particle size, must be determined from aliquots taken prior to centrifuging. After centrifuging, and prior to heating or acid digestion, aliquots of the sediment sample will be collected. These aliquots will be used by the laboratory for analyses that are sensitive to either drying or acid digestion.

The laboratory will analyze each aliquot as directed in the AI. Each sub-sample taken from that aliquot must go through separate sample preparation, if sample preparation is required. If a sufficient amount of dried sediment is not available for the acid digestion step, then the project may need to take additional samples for the "other" required analyses; this will be at the direction of the ERC project engineer.

The analytical tests for the sediment are provided in Table 1. Detailed instructions to the analytical laboratory will be provided by an AI prior to shipment of the samples. 
Table 1. Required Analytical Parameters, Analytical Methods, and Target Practical Quantitation Limits for the $105-\mathrm{N}$ Basin (North Cask Pit) Sediment Sample(s). (Page 1 of 3)

\begin{tabular}{|c|c|c|}
\hline Analytical Parameter & Analytical Method & Target Practical Quantitation Limit \\
\hline \multicolumn{3}{|c|}{ Radiological Analyses } \\
\hline Gross Alpha & Gas Proportional Counting & $0.05 \mu \mathrm{Ci} / \mathrm{g}$ \\
\hline Gross Beta & Gas Proportional Counting & $0.1 \mu \mathrm{Ci} / \mathrm{g}$ \\
\hline $\begin{array}{l}\text { Americium-241 } \\
\text { Antimony-125 } \\
\text { Cobalt-60 } \\
\text { Cesium-134 } \\
\text { Cesium-137 } \\
\text { Europium-152 } \\
\text { Europium-154 } \\
\text { Europium-155 } \\
\text { Radium-226 } \\
\text { Radium-228 (Ac-228) }\end{array}$ & Gamma Energy Analysis (GEA) & $\begin{array}{l}0.05 \mu \mathrm{Ci} / \mathrm{g} \\
0.05 \mu \mathrm{Ci} / \mathrm{g} \\
0.05 \mu \mathrm{Ci} / \mathrm{g} \\
0.05 \mu \mathrm{Ci} / \mathrm{g} \\
0.05 \mu \mathrm{Ci} / \mathrm{g} \\
0.05 \mu \mathrm{Ci} / \mathrm{g} \\
0.05 \mu \mathrm{Ci} / \mathrm{g} \\
0.05 \mu \mathrm{Ci} / \mathrm{g} \\
0.05 \mu \mathrm{Ci} / \mathrm{g} \\
0.05 \mu \mathrm{Ci} / \mathrm{g}\end{array}$ \\
\hline Strontium-90 & $\begin{array}{l}\text { Chemical Separation/Beta } \\
\text { Proportional Counting }\end{array}$ & $0.05 \mu \mathrm{Ci} / \mathrm{g}$ \\
\hline Uranium Isotopic & ICP/MS & $0.1 \mu \mathrm{Ci} / \mathrm{g}$ per isotope \\
\hline $\begin{array}{l}\text { Americium-241 } \\
\text { Curium-244 }\end{array}$ & $\begin{array}{l}\text { Chemical Separation/Alpha } \\
\text { Energy Analysis }\end{array}$ & $0.02 \mu \mathrm{Ci} / \mathrm{g}$ \\
\hline $\begin{array}{l}\text { Plutonium-238 } \\
\text { Plutonium-239/240 }\end{array}$ & $\begin{array}{l}\text { Chemical Separation/Alpha } \\
\text { Energy Analysis }\end{array}$ & $\begin{array}{l}0.02 \mu \mathrm{Ci} / \mathrm{g} \\
0.02 \mu \mathrm{Ci} / \mathrm{g}\end{array}$ \\
\hline \multicolumn{3}{|c|}{ Chemical Analyses } \\
\hline $\mathrm{pH}$ & pH Electrode & $0.1 \mathrm{pH}$ unit \\
\hline $\begin{array}{l}\text { Total Metals: } \\
\text { Aluminum } \\
\text { Antimony } \\
\text { Arsenic } \\
\text { Barium } \\
\text { Beryllium } \\
\text { Cadmium } \\
\text { Chromium } \\
\text { Iron } \\
\text { Manganese } \\
\text { Nickel } \\
\text { Silicon } \\
\text { Silver } \\
\text { Sodium } \\
\text { Vanadium } \\
\text { Zinc }\end{array}$ & SW-846/6010A (ICP) & $\begin{array}{c}20 \mathrm{mg} / \mathrm{Kg} \\
40 \mathrm{mg} / \mathrm{Kg} \\
100 \mathrm{mg} / \mathrm{Kg} \\
150 \mathrm{mg} / \mathrm{Kg} \\
0.25 \mathrm{mg} / \mathrm{Kg} \\
3.5 \mathrm{mg} / \mathrm{Kg} \\
15 \mathrm{mg} / \mathrm{Kg} \\
10 \mathrm{mg} / \mathrm{Kg} \\
2 \mathrm{mg} / \mathrm{Kg} \\
100 \mathrm{mg} / \mathrm{Kg} \\
3 \mathrm{mg} / \mathrm{Kg} \\
6 \mathrm{mg} / \mathrm{Kg} \\
60 \mathrm{mg} / \mathrm{Kg} \\
4.5 \mathrm{mg} / \mathrm{Kg} \\
3 \mathrm{mg} / \mathrm{Kg}\end{array}$ \\
\hline $\begin{array}{l}\text { Lead } \\
\text { Selenium } \\
\text { Thallium }\end{array}$ & $\begin{array}{l}\text { or SW-846/7421 (GFAA) } \\
\text { or SW-846/7740 (GFAA) } \\
\text { or SW-846/7841 (GFAA) }\end{array}$ & $\begin{array}{c}7 \mathrm{mg} / \mathrm{Kg} \\
3 \mathrm{mg} / \mathrm{Kg} \\
1.5 \mathrm{mg} / \mathrm{Kg}\end{array}$ \\
\hline
\end{tabular}


Table 1. Required Analytical Parameters, Analytical Methods, and Target Practical Quantitation Limits for the 105-N Basin (North Cask Pit) Sediment Sample(s). (Page 2 of 3)

\begin{tabular}{|c|c|c|}
\hline Analytical Parameter & Analytical Method & Target Practical Quantitation Limit \\
\hline Mercury & $\begin{array}{l}\text { CoKgd Vapor AA, } \\
\text { SW-846/7471 }\end{array}$ & $0.5 \mathrm{mg} / \mathrm{L}$ \\
\hline $\begin{array}{l}\text { TCLP Metals: } \\
\text { Antimony } \\
\text { Arsenic } \\
\text { Barium } \\
\text { Beryllium } \\
\text { Cadmium } \\
\text { Chromium } \\
\text { Lead } \\
\text { Nickel } \\
\text { Selenium } \\
\text { Silver } \\
\text { Thallium } \\
\text { Vanadium } \\
\end{array}$ & $\begin{array}{l}\text { SW-846/1311 (extraction) } \\
\text { SW-846/6010A (ICP) }\end{array}$ & $\begin{array}{c}2 \mathrm{mg} / \mathrm{L} \\
5 \mathrm{mg} / \mathrm{L} \\
7 \mathrm{mg} / \mathrm{L} \\
0.01 \mathrm{mg} / \mathrm{L} \\
0.19 \mathrm{mg} / \mathrm{L} \\
0.8 \mathrm{mg} / \mathrm{L} \\
0.37 \mathrm{mg} / \mathrm{L} \\
5 \mathrm{mg} / \mathrm{L} \\
0.16 \mathrm{mg} / \mathrm{L} \\
0.3 \mathrm{mg} / \mathrm{L} \\
0.08 \mathrm{mg} / \mathrm{L} \\
0.2 \mathrm{mg} / \mathrm{L} \\
\end{array}$ \\
\hline Mercury & $\begin{array}{l}\text { SW-846/1311 (extraction) } \\
\text { SW-846/7471 (CVAA) }\end{array}$ & $0.02 \mathrm{mg} / \mathrm{L}$ \\
\hline $\begin{array}{l}\text { Polychlorinated Biphenyls } \\
\text { (PCBs) }\end{array}$ & $\begin{array}{l}\text { Gas Chromatography, } \\
\text { SW-846/8080A }\end{array}$ & $10 \mathrm{mg} / \mathrm{Kg}$ \\
\hline $\begin{array}{l}\text { Anions } \\
\text { Bromide } \\
\text { Chloride } \\
\text { Fluoride } \\
\text { Nitrate } \\
\text { Nitrite } \\
\text { Phosphate } \\
\text { Sulfate }\end{array}$ & $\begin{array}{l}\text { Ion Chromatography, } \\
\text { SW-846/9056 }\end{array}$ & $\begin{array}{l}5 \mathrm{mg} / \mathrm{Kg} \\
5 \mathrm{mg} / \mathrm{Kg} \\
5 \mathrm{mg} / \mathrm{Kg} \\
5 \mathrm{mg} / \mathrm{Kg} \\
5 \mathrm{mg} / \mathrm{Kg} \\
5 \mathrm{mg} / \mathrm{Kg} \\
5 \mathrm{mg} / \mathrm{Kg}\end{array}$ \\
\hline Cyanide & $\begin{array}{l}\text { Distillation/colorimetric } \\
\text { SW-846 } 9010\end{array}$ & $10 \mathrm{mg} / \mathrm{Kg}$ \\
\hline $\begin{array}{l}\text { Total Organic Carbon } \\
\text { (TOC) }\end{array}$ & Combustion, Coulemetric & $200 \mathrm{mg} / \mathrm{Kg}$ \\
\hline $\begin{array}{l}\text { Total Inorganic Carbon } \\
\text { (TIC) }\end{array}$ & $\begin{array}{l}\text { Acidification, Coulemetric } \\
\text { SW-846/9060 modified }\end{array}$ & $50 \mathrm{mg} / \mathrm{Kg}$ \\
\hline Hydroxide Demand & Titration & NA \\
\hline
\end{tabular}


Table 1. Required Analytical Parameters, Analytical Methods, and Target Practical Quantitation Limits for the 105-N Basin (North Cask Pit) Sediment Sample(s). (Page 3 of 3)

\begin{tabular}{|c|c|c|}
\hline Analytical Parameter & Analytical Method & Target Practical Quantitation Limit \\
\hline \multicolumn{3}{|c|}{ Physical Analyses } \\
\hline $\begin{array}{l}\text { Particle Size; } \\
\text { Mean and Distribution }\end{array}$ & $\begin{array}{l}\text { Particle Size Distribution } \\
\text { Analyzer }\end{array}$ & NA \\
\hline $\begin{array}{l}\text { Density (settled and } \\
\text { centrifuged) }\end{array}$ & Gravimetric & NA \\
\hline Percent Solids & Gravimetric & NA \\
\hline Percent Moisture & Gravimetric & NA \\
\hline Viscosity (at 70E F) & Physical Measurement & NA \\
\hline $\begin{array}{l}\text { Endotherm/Exotherm } \\
\text { Evaluation }\end{array}$ & $\begin{array}{l}\text { Differential Scanning } \\
\text { Calorimeter }\end{array}$ & NA \\
\hline \multicolumn{3}{|c|}{ Alternate Analytical Techniques } \\
\hline $\begin{array}{l}\text { Unit Mass -Mass } \\
\text { Spectroscopy }\end{array}$ & $\begin{array}{l}\text { Laser Ablation Mass } \\
\text { Spectrometry }\end{array}$ & To be Established and Evaluated \\
\hline
\end{tabular}

Note: Additional analyses may be added prior to sampling. Additions will be noted in the work control package. 
BHI-00984

Rev. 0

\subsection{HEALTH AND SAFETY}

All field operations will be performed in accordance with BHI health and safety requirements found in BHI-SH-01, Hanford ERC Environmental, Safety, and Health Program and the requirements of HSRCM-1, Hanford Site Radiological Control Manual. A work control package will be prepared in accordance with BHI-MA-02. The package will include an activity hazard analysis, or site-specific health and safety plan, and applicable radiological work permits.

\subsection{ALARA PLAN}

The sampling procedure and associated activities will take into consideration exposure reduction techniques which will minimize the radiation exposure to the sampling team, as required by BHI-QA-01, ERC Quality Program, and BHI-SH-01.

As low as reasonably achievable (ALARA) considerations will be an integrated part of the design effort for the sampling and sampling equipment to minimize personnel exposure. The following exposure reduction techniques (or their equivalent) will be used during the sampling process:

C Approved procedures will be used that take into account the anticipated radiation exposure rate levels.

C Personnel will be trained prior to using the procedures.

C Shielding and/or remote operation of the equipment will be used where possible.

C Time required to collect samples will be minimized through a thorough analysis of each sampling activity.

C A survey meter will be used to monitor the sample bottles to minimize unplanned exposure to personnel.

C A contingency procedure will be provided for use when sampling problems arise, and an alternate radiation work permit will be provided for use in the event of accidents.

C As required, health physics staff will conduct a pre-job meeting with the sampling team, and the task lead will conduct a daily briefing with the sampling team on the planned activities for that day.

C Hand exposure during sample transfers will be monitored using finger ring thermoluminescent dosimeters, if required. 
BHI-00984

Rev. 0

C Members of the sampling team, including observers, will be limited to only those absolutely necessary to properly perform the sampling activities.

C Health physics personnel will establish dose rate "standby areas" for the sampling team members.

As a result of the above ALARA actions, estimates of the overall total whole body exposure will be projected and closely monitored for the sampling team personnel and the radiation technician.

\subsection{QUALITY ASSURANCE PROJECT PLAN}

The QA/QC established for this sampling and analysis activity are identified in this QAPjP. The total error in the analytical results will be controlled to ensure that an acceptable level of confidence is maintained in the decisions resulting from a review of the data.

\subsection{PROJECT ORGANIZATION AND RESPONSIBILITY}

\subsubsection{Technical Lead Responsibility}

The 105-N Basin Clean Out Project Engineer is primarily responsible for directing and approving all technical aspects of this sampling and analysis task. Additional responsibilities include coordinating efforts of functional and support organizations and evaluating and selecting external subcontractors as needed to complete the required task activities.

\subsubsection{Support Responsibilities}

The 105-N Basin project personnel in conjunction with the ERC's Field Sampling organization will be responsible for performing sample collection and shipping activities. The ERC's SDM organization is responsible for arranging for laboratory analytical services. The PHMC's $222-S$ Analytical Laboratory will be responsible for analytical services, as outlined in this SAP, the project SAF/FSR, and the AI. Health and safety documentation and field monitoring will be provided by ERC's Health and Safety organization and Radiological Support organization. These organizations will be responsible for performing all services in accordance with the requirements outlined in this SAP.

\subsection{SAMPLING PROCEDURES}

All sampling, sample packaging, and sample shipping will be performed in accordance with procedures identified in BHI-EE-01, Environmental Investigations Procedures. Procedures for sampling activities not covered in this manual will be prepared by project personnel, identified in 
BHI-00984

Rev. 0

the FSP, and attached to the work control package. Procedures will be carefully followed during the field sampling activities to ensure that the samples collected are representative of the sediment in the 105-N Basin, North Cask Pit.

\subsection{SAMPLE CUSTODY}

\subsubsection{Field Custody}

To ensure the defensibility of the analytical data, sample chain-of-custody will be maintained at all times, from the time the sample is collected to the time the sample is disposed. All samples obtained during the course of this project will be controlled from the point of origin to the analytical laboratory, as required by BHI-EE-01, EIP 3.0.

\subsubsection{Laboratory Custody Procedure}

Sample custody during laboratory analysis will be addressed in the $222-S$ Analytical Laboratory's standard operating procedures. Laboratory custody procedures will ensure the maintenance of sample integrity and identification throughout the analytical process.

\subsubsection{Final Evidence Custody Procedure}

All relevant documents, records, reports, logs, field notebooks, pictures, subcontract reports, and analytical reports will be submitted, secured, and stored in accordance with the Document and Information Services section of BHI-MA-02, ERC Project Procedures.

\subsection{ANALYTICAL PROCEDURES}

Analytical methods to be used by $222-S$ will be specified by completing a request for analytical services (form BHI-EE-003) and in accordance with BHI-EE-01 (Section 2.0), the project AI, or the contractor procurement document. The ERC's SDM will issue a SAF/FSR identifying analytical methods, volume requirements, holding times, and bottle requirements. Site-specific analytical methods are identified in the FSP.

\subsection{OBJECTIVES FOR ANALYTICAL MEASUREMENTS}

The rationale for establishing DQOs and data needs for this sampling task are discussed in the DQO Summary Report for 105-N Basin Sediment Disposition (BHI 1996a). Parameters have been established for each of the five data assessment areas of precision, accuracy, representativeness, comparability, and completeness (PARCC), and the parameters are identified in the following sections. These objectives are expressed as qualitative statements concerning 
BHI-00984

Rev. 0

the type of data needed to support a decision, based on a specific level of uncertainty. In addition, where applicable, the PARCC parameters will comply with the $222-S$ Laboratory Quality Assurance Plan (WHC 1995).

\subsubsection{Precision}

Precision is the measure of mutual agreement among replicate (or between duplicate) or co-located sample measurements of the same analyte. The closer the number values of the measurements are to each other, the more precise the measurement. Precision for a single analyte will be expressed as a percentage of the difference between results of replicate samples or matrix spike duplicates. For all laboratory analyses, precision is \pm 30 percent. Deviations will be documented in the data report.

\subsubsection{Accuracy}

Accuracy is a measure of bias in a measurement system. The closer the value of the measurement agrees with the true value, the more accurate the measurement. This will be expressed as the percent recovery of a known spike analyte or a standard reference sample. For all laboratory analyses, accuracy is \pm 2 sigma for the laboratory control sample or $100 \% \pm 30 \%$ recovery for spiked samples. Deviations will be documented in the data report.

\subsubsection{Representativeness}

Representativeness will be achieved by using BHI-approved sampling methods, and by homogenizing the Sediment in the North Cask Pit and by compositing three samples into one.

\subsubsection{Comparability}

Comparability expresses the confidence with which one data set can be compared to another data set given similar precision, accuracy, detection limit, analytical method, and sample matrix. Because the analytical data do not need to be compared with other laboratory or field screening techniques, comparability for this project will not be quantified.

\subsubsection{Completeness}

Completeness measures the amount of valid data obtained from a measurement system compared to the amount that was expected to be obtained under normal conditions.

$$
\% \mathrm{C}=100 \times \mathrm{V} / \mathrm{n}
$$

where: $\quad \mathrm{V}=$ number of valid data points acquired

$\mathrm{n}=$ total number of data points.

At a minimum, the analytical data for this project should be $90 \%$ complete. 
BHI-00984

Rev. 0

\subsection{CALIBRATION PROCEDURES}

All sampling and analytical equipment used in this plan will be calibrated to operate within the specifications provided by the manufacturer. Calibrations will be performed as stipulated by the manufacturer's calibration procedure, the project-specific calibration procedure, or an analytical method. These calibration procedures are addressed in the $222 \&$ Laboratory Quality Assurance Plan (WHC 1995) and the sampling tool procedure. For radiological screening instruments, source/response checks will be performed.

\subsection{INTERNAL QUALITY CONTROL}

Several QC samples are usually introduced into the collection and analytical system to monitor the adequacy of the sampling system and the integrity of samples during their journey from the field collection point through laboratory analysis. The QC samples for the field sample collection process and the laboratory analyses are defined in the following sections with their methods of collection and purpose.

\subsubsection{Field Quality Control Requirements}

3.7.1.1 Equipment Rinsate Blank. One equipment rinsate blank will be collected to assess the cleanliness of the sampling equipment and the effectiveness of the sample equipment decontamination process. The equipment blank will be collected using ASTM Type II water passed through the decontaminated sampling equipment prior to use. The rinsate blank will be analyzed for the same radionuclide and chemical analysis as the actual sample collected during use of the equipment.

3.7.1.2 Field Duplicate Sample. Field duplicates are two samples produced from the same material and collected in the same location. Field duplicates provide information concerning the homogeneity of the matrix, as well as an evaluation of the precision of the sampling and analysis process. A field duplicate will not be collected for Phase 2 of the $105-\mathrm{N}$ Basin sediment disposition project.

\subsubsection{Analytical Laboratory Quality Control Requirements}

The following QC requirements pertain to the PHMC's 222-S Analytical Laboratory. The laboratory's QC requirements are stipulated in the laboratory's quality assurance plan (WHC 1995) or by the appropriate analytical method.

3.7.2.1 Matrix Spike Samples. Matrix spike samples require the addition of a known quantity of a representative analyte of interest to the sample as a measure of recovery percentage. The spike shall be made in a replicate of a field sample. Replicate samples are separate aliquots removed from the same sample container in the laboratory. Spike compound selection, quantities, and concentrations will be described in the analytical procedures. The $222-\mathrm{S}$ 
BHI-00984

Rev. 0

Analytical Laboratory will perform one matrix spike and one matrix spike duplicate per sampling event, or as appropriate for the analytical method.

3.7.2.2 Replicate Samples. Replicate samples are separate aliquots removed from the same sample container in the laboratory. If there is enough sample, the $222-S$ Analytical Laboratory will perform one replicate per sampling event.

3.7.2.3 Quality Control Reference Samples. The QC reference samples will be prepared from an independent standard, wherever possible, at a concentration other than that used for calibration, but within the calibration range. Reference samples are required as an independent check on analytical technique and methodology. The 222-S Analytical Laboratory will perform one reference sample per analytical batch, as applicable.

3.7.2.4 Analytical Blanks. Analytical blanks are materials known to be free from contamination that are carried through the same analytical procedure as the sample using the same reagents. They are used to evaluate potential laboratory contamination of samples. The $222-S$ Analytical Laboratory will perform one blank analysis per analytical batch, as applicable.

\subsection{DATA REPORTING AND MANAGEMENT}

\subsubsection{Reporting}

The laboratory must prepare a report summarizing the analysis results. Data summaries shall include, at a minimum, sample identity, sampling and analysis dates, and reduced data results. The laboratory's project lead will prepare a final report including data results and a case narrative discussing whether or not the DQOs and PARCC parameters were met.

\subsubsection{Validation}

Validation will not be required by this QAPjP for Phase 2 of the 105-N Basin sediment disposition project.

\subsubsection{Data Management}

Data generated as a result of laboratory analysis will be managed and stored by the ERC's SDM organization, as outlined in BHI-EE-01, Section 2.0, "Sample Management."

All validated data reports and supporting analytical data packages shall be subject to final technical review by qualified reviewers before their submittal to regulatory agencies or inclusion in reports or technical memoranda, at the direction of the BHI Project Task Lead. Electronic data access, when appropriate, will be through computerized data bases (e.g., HEIS). Where electronic data are not available, hard copies will be provided in accordance with Section 9.6 of the Hanford Federal Facility Agreement and Consent Order (Ecology et al. 1990). 
BHI-00984

Rev. 0

\subsection{PERFORMANCE AND SYSTEMS AUDITS}

The BHI QA organization may conduct random surveillance and assessments to verify compliance with the requirements outlined in this QAPjP, the project work package, the BHI quality management plan, and $\mathrm{BHI}$ procedures and regulatory requirements. The surveillance and assessments will collectively address quality-affecting activities that include, but are not limited to, measurement system accuracy, field activities, data collection, processing, validation, management, and QA programs.

Random surveillance and assessments will be structured to meet the following system and performance audit classification. System audits consist of the evaluation of the components of the measurement systems to determine their proper selection and use. Performance audits ensure the accuracy of the total system and its individual parts.

\subsection{PREVENTIVE MAINTENANCE}

All measurement and testing equipment used in the field and in the laboratory that directly affects the quality of the analytical data will be subject to preventive maintenance measures that ensure minimization of measurement system downtime. Laboratories and field screening organizations must maintain their equipment. Maintenance requirements, such as parts lists and instructions, will be included in the $222-\mathrm{S}$ and field screening organization QA plans or operating procedures.

\subsection{DATA ASSESSMENT PROCEDURES}

Analytical data will first be compiled and reduced by the laboratory and validated in a manner appropriate for the individual analytical method. As directed by the technical lead, various statistical and probabilistic techniques may be selected for use in the process of data comparison and analysis. The statistical methodology and the assumptions to be made will be defined by written directions that are signed, dated, and retained as project records.

\subsection{CORRECTIVE ACTION}

Corrective action required as a result of surveillance reports, nonconformance reports, or audit activities will be documented and dispositioned, as required by BHI-MA -02 , Procedure 2.1, "Corrective Action." Other measurement systems, procedures, or plan corrections that may be required as a result of routine review processes will be resolved as required by governing procedures or will be referred to the technical lead for resolution. 
BHI-00984

Rev. 0

\subsection{QUALITY ASSURANCE REPORTS}

Project activities may be regularly assessed by random audits, surveillance, and assessments. All findings from audits, surveillance, and assessments will be transmitted to the project manager and the BHI QA organization for program-related tracking and trending.

\subsection{REFERENCES}

BHI-EE-41, Environmental Investigation Procedures, Bechtel Hanford, Inc., Richland, Washington.

BHI-MA-02, ERC Project Procedures, Bechtel Hanford, Inc., Richland, Washington.

BHI-QA-01, ERC Quality Program, Bechtel Hanford, Inc., Richland, Washington.

BHI-SH-01, Hanford ERC Environmental, Safety, and Health Program, Bechtel Hanford, Inc., Richland, Washington.

BHI-SH-04, Radiological Control Work Instructions, Bechtel Hanford, Inc., Richland, Washington.

BHI, 1996a, Data Quality Objectives Summary Report for 105 N Basin Sediment Disposition, BHI-00930, Rev. 0, Bechtel Hanford, Inc., Richland, Washington.

BHI, 1996b, Engineering Evaluation/Cost Analysis for 100-N Area Waste, BHI-00785, Rev. 0, Bechtel Hanford, Inc., Richland, Washington.

BHI, 1997, 105 N Basin Sediment Disposition Phase-One Sampling and Analysis Plan, BHI-00975, Rev. 1, Bechtel Hanford, Inc., Richland, Washington.

Ecology, EPA, and DOE, 1990, Hanford Federal Facility Agreement and Consent Order, 2 vols., as amended, Washington State Department of Ecology, U.S. Environmental Protection Agency, and U.S. Department of Energy, Olympia, Washington.

EPA, 1994, Guidance for the Data Quality Objectives Process, EPA-QA/G-4, U.S. Environmental Protection Agency, Washington, D.C.

WHC, 1995, 222 \& Laboratory Quality Assurance Plan, WHC-SD-CP-QAPP-016, Rev. 1, Westinghouse Hanford Company, Richland, Washington. 